\title{
Penerapan Pendekatan Kontekstual (CTL) Untuk Meningkatkan Hasil Belajar Mahasiswa Program Studi PGSD UNM Kampus Parepare Pada Mata Kuliah PKn I
}

\author{
Ritha Tuken ${ }^{1}$, Yonathan Saba' Pasinggi ${ }^{2}$ \\ ${ }^{1,2}$ Progam Studi PGSD, Universitas Negeri Makassar \\ ritha.tuken@unm.ac.id \\ yonathan.s.pasinggi@unm.ac.id
}

\begin{abstract}
ABSTRAK
Penelitian ini bertujuan untuk mengetahui penerapan pendekatan contekstul (CTL) yang dilakukan dosen dalam meningkatkan hasil belajar mahasiswa dalam pembelajaran PKn1. Hal ini dilakukan untuk menentukan arah dan kebijakan dalam meningkatkan hasil belajar mahasiswa pada pembelajaran PKn1. Penelitian ini menggunakan pendekatan kualitiatif, jenis penelitian yaitu penelitian tindakan kelas yang berlokasi di Prodi PGSD UNM Kampus Parepare. Pemilihan lokasi ini berdasarkan pertimbangan peneliti melihat penerapan pendekatan kontekstual teaching and learning (CTL) dalam mata kuliah PKn 1, oleh dosen masih kurang mampu diterapkan dengan baik. Prosedur Penelitian PTK yaitu (1) Perencanaan, (2) Pelaksanaan, (3) observasi, (4) refleksi. Teknik pengumpulan data yang digunakan dalam penelitian ini meliputi (1) observasi, (2) Dokumentasi, (3) Wawancara, (4) tes. Analisis data merupakan upaya meningkatkan hasil belajar mahasiswa dengan penerapan pendekatan kontekstual. Hasil penelitian pada tes awal menunjukan bahwa kemampuan mahasiswa memahami materi pelajaran masih dalam kategori kurang, setelah dilakukan pembelajaran menunjukkan peningkatan yang signifikan dengan hasil evaluasi pada siklus I berada pada kualifikasi cukup (c), penelitian dilanjutkan pada siklus ke II karena peneliti belum puasdengan hasil yang diperoleh pada siklus I, hasil evaluasi pada siklus II menunjukkan peningkatan yang signifikan hasilnya pada kategori sangat baik. Hal ini menunjukkan bahawa penerapan pendekatan kontekstual pada pembelajaran PKn1 dapat meningkatkan hasil belajar mahasiswa di Prodi PGSD UNM Kampus Parepare.
\end{abstract}

Kata kunci: pendekatan contekstul (CTL), pembelajaran PKn1

\section{PENDAHULUAN}

Pendidikan Nasional dalam UUD 1945

Pasal 31 Ayat 3, pemerintah mengusahakan dan menyelenggarakan satu sistem pendidikan nasional, yang meningkatkan keimanan dan ketakwaan serta akhlak mulia dalam rangka mencerdaskan kehidupan bangsa, sebagaimana diatur dalam undang-undang. sajian perkuluahan dalam mata kuliah PKn bertujuan untuk membekali mahasiswa dalam pendidikan budi pekerti yang luhur, penguasaan pengetahuan serta kemampuan dasar dalam hubungan dengan sesama warga negara serta pendidikan bela negara yang diterapkan oleh bangsa dan negara.

Suatu pemikiran berkembang dewasa ini berkaitan degan proses perkuliahan diharapkan mahasiswa mengikuti kuliah lebih baik bila dikondisikan sesuai lingkungannya secara alamiah. Perkuliahan seperti ini mahasiswa dibiasakan mengikuti perkuliahan agar nantinya apabila sudah mengajar dapat diterapkan bahwa belajar lebih bermakna jika peserta didik mengalami sendiri tentang apa yang dia pelajari sehingga dapat tertanam baik pada dirinya. Perkuliahan semacam ini berorientasi pada pemahaman serta penguasaan matakuliah terbukti berhasil dalam menguasai kompetensi-kompetensi sebab langsung mengalamiminya sendiri untuk membekali mahasiswa dalam memecahkan masalah perlu dibiasakan mengingat perkembangan pengetahuan dimasa yang akan datang.

Proses perkuliahan akan berjalan secara alamiah apabila mahasiswa langsung ditugaskan untuk bekerja bekerja dan mengalami sendiri, pengetahuan bukan transfer dari dosen, dengan perkulaihan ini, hasil perkuliahan diharapkan lebih bermakna bagi 
mahasiswa untuk memecahkan masalahnya, berfikir kritis, dan melakukan pengamatan serta dapat menarik kesimpulan untuk pemikiran jangka panjangnya. Dalam perkuliahan seperti itu, mahasiswa perlu di bekali untuk mengetahui apa makna dari belajar, bagaimana manfaatnya, status apa dalam belajar, serta bagaimana cara mencapainya.

Contekstual Teaching and Learning (CTL), merupakan salah satu strategi untuk melibatkan mahasiswa secara penuh dalam proses perkuliahan. Mahasiswa diharapkan dalam beraktivitas mengkaji matakuliah sesuai dengan topik yang di pelajarinya. Belajar dalam conteks (CTL) tidak hanya sekedar untuk mendengarkan dan mencatat, tetapi belajar melaui situai nyata, berpengalaman secara langsung dalam proses perkuliahan itu serta diharapkan perkembangan pengetahuan mahasiswa terjadi secara utuh, tidak hanya dari aspek kongnitif saja, melainkan juga dari aspek afektif serta psikomotorik.

Wina Sanjaya (2007) menjelaskan bahwa pembelajaran pendekatan kontekstual (CTL) adalah suatu strategi pembelajaran yang penekanannya pada proses, siswa dilibatkan penuh dalam memaknai dan menemukan sendiri materi yang dipelajari serta dapat mengaitkan materi dalam situasi nyata disekitarnya serta mendorong siswa dalam memaknai dan mengaplikasikan dalam kehidupannya.

Melalui konsep yang dijelaskan di atas ada tiga hal yang perlu dipahami yakni (1) CTL penekanannya melalui proses keterlibatan mahasiswa untuk dapat menemukan materi, artinya proses perkuliahan diorientasikan pada proses pengalaman langsung. Proses perkuliahan dalam konteks CTL mahasiswa diharapkan terlibat memahani secara langsung dalam perkuliahan, dosen hanya mendampingi bagaimana proses mencari dan menemukan sendiri topik yang dipelajari. (2) CTL mendorong mahasiswa dalam menemukan hubungan antara topik dengan situasi nyata disekitarnya, artinya mahasiswa diharapkan untuk terlibat langsung dalam kegiatan perkuliahan bagaiman hubungan antara pengalaman belajar di luar kelas dengan kehidupan nyata. (3) CTL mendorong mahasiswa dapat menerapkan pengetahuannya dalam kehidupan nyata, artinya CTL bukan hanya mengharapkan mahasiswa untuk memahami topik yang dikajinya, tetapi bagaimana topik dikaji itu dapat mewarnai perilakunya dalam kehidupan sehari-hari.

Bobbi Deporter (1992), bahwa setiap siswa mempunyai gaya belajar yang berbeda . Perbedaan tersebut merupakan sebagai unsur modalitas belajar. Menurutnya ada tiga tipe gaya dalam belajar siswa, yaitu tipe visual, auditorial, dan kinestesis. Tipe visual adalah gaya belajar dengan cara melihat, artinya siswa lebih cepat belajar dengan menggunakan indera penglihatannya. Tipe auditorial adalah tipe belajar dengan menggunakan alat pendengarannya, sedangkan tipe kinestesis adalah tipe belajar dengan bergerak, bekerja, dan menyentuh.

Dalam proses perkuluahan pembelajaran kontekstual, setiap dosen perlu memaknai tipe belajar pada setisp mahasiswa, artinya dosen perlu menyesuaikan perkuliahan terhadap gaya belajar mahasiswa. Sejalan dengan pembelajaran kontekstual, terdapat beberapa hal yang perlu diperhatikan oleh setiap dosen pembelajaran pendekatan kontekstual (CTL).

1. Mahasiswa pada perkuliahan melalui pendekatan kontekstual pandang sebagai individu yang sedang berkembang. Cara belajar seseorang dapat dipengaruhi oleh tingkat perkembanganemosional mahasiswa, serta kebebasan dalam memaknaisuatu konsep sesuai dengan pengalaman yang dimilikinya. Mahasiswa sudah di beri kebebasan dalam mengembangkan pola pikirnya dimana kelak menjad guru dapat menghadapi anak-anak yang belum dewasa, melainkan organisme yang berada pada tahap-tahap perkembangan. Cara belajar sangat dipengaruhi oleh tingkat perkembangan siswa melalui pengalaman yang dialaminya. Sebagai mahasiswa harus memahami peran segagai guru bukanlah sebagai instruktur atau "penguasa" dalam melaksanakan tugasnya untuk membimbing dan mengarahkan siswa guru diharapkan 
sebagai pasilitator untuk pembimbing siswa sehingga mereka dapat memahami konsep sesuai dengan tahap perkembangannya.

2. Setiap mahasiswa untuk mengembangkan dirinya memiliki kecenderungan belajar sesuai dengan tingkat penguasaannya baik dalam halhal yang baru dengan penuh tantangan. Mahasiswa sebagai calon guru diharapkan dapat memahami perkembangan siswa dalam memahami konsep adalah yang disesuaikan dengan tingkat perkembangan siswa hal-hal yang dianggap baru melalui dunia nyata. Pembelajaran yang akan dilakukan pada siswa diharapkan mereka dapat menemukan sendiri daalam mencoba memecahkan setiap permasalahan yang menantang. Untuk memberikan materi, guru dalam pembelajarannya memilih bahan-bahan belajar yang dianggap penting untuk dipelajari oleh siswa.

\section{METODE PENELITIAN}

Pendekatan penelitian ini adalah pendekatan kualititif dan jenis penelitian yaitu penelitian tindakan kelas yang berlokasi di Prodi PGSD UNM Kampus Parepare. Penelitian ini dilaksanakan selama tiga bulan. Secara garis besar, prosedur / pengembangan tindakan dapat dilakukan melalui lima tahap kegiatan yakni tahap orentasi, perencanaan, tindakan, observasi dan refleksi (Hopkins. 1993).

Lembar observasi digunakan dalam mengumpulkan data melalui pengamatan ketika proses perkuliahan berlangsung. Untuk pengambilan hasil belajar mahasiswa dibuatkan soal (tes tertulis) dan dilakukan terhadap mahasiswa setelah pelaksanaan tindakan proses perkuliahan telah berakhir. Tes tersebut diberikan kepada seluruh mahasiswa Prodi PGSD UNM Kampus Parepare. Hasil tes akan dimanfaatkan untuk merefleksi pemahaman mahasiswa terhadap isi materi yang diberikan. Dari hasil observasi dan tes tertulis diberikan kepada mahasiswa setelah dianalisis dapat dijadikan dasar untuk tindakan (siklus) selanjutnya.

Data yang digunakan dalam penelitian ini adalah: (1) dokumentasi penyusunan rencana pembelajaran, (2) hasil observasi pelaksanaan/aktivitas peneliti dan mahasiswa dalam pembelajaran Pkn (3) nilai/hasil belajar mahasiswa dengan topik sistem pemerintahan desa dan kecamatan.

\section{HASIL \& PEMBAHASAN}

Pelaksanaan penelitian tindakan kelas yang dilaksanakan terdiri dari dua siklus. Tiap siklus terdiri dari dua kali pertemuan yang dilaksanakan sesuai dengan prosedur penelitian. Pada penelitian ini berhenti setelah pelaksanaan siklus kedua karena telah tercapai target keberhasilan yang telah ditetapkan.

\section{Siklus I}

Pada siklus I, penerapan pendekatan kontekstual belum diterapkan secara maksimal masih terdapat kelemahan disana sini yang perlu diperbaiki pada tindakan berikutnya. Hal ini terlihat dari hasil observasi yang telah dilaksanakan oleh peneliti bersama dengan dosen yang menunjukkan masih ada fase-fase yang belum sepenuhnya terlaksana yakni pada fase I saat dosen menyampaikan tujuan perkuliahan, memberikan pengetahuan awal terlihat sebagian mahasiswa belum memperhatikan penjelasan dari dosen, masih ada mahasiswa yang saling mengganggu serta masih ada yang keluar masuk ruangan. Kemudian pada fase $\mathrm{V}$ hanya sebagian besar mahasiswa yang mampu mempresentasekan hasil kerja kelompoknya karena masih gugup untuk berbicara.

Selanjutnya untuk mengetahui pemahaman mahasiswa terhadap materi perkuliahan diadakan tes evaluasi secara individu pada tindakan. Adapun perolehan nilai hasil belajar yang dicapai mahasiswa pada tes evaluasi siklus I yaitu skor rata-rata kelas $61,75 \%$. Hasiltes rata-rata tersebut masih berada pada tingkat kualifikasi cukup (c). data ini menunjukkan bahwa ada 4 mahasiswa yang mendapat nilai amat baik, 8 mahasiswa mendapat nilai baik, 20 mahasiswa mendapat nilai cukup, 4 mahsiswa mendapat nilai kurang dan 24 mahasiswa mendapat nilai kurang sekali. Dari penguasaan mahasiswa dari lima kategori mulai dai kurang sekali sampai amat baik dapat disimpulkan bahwa masih ada 30 mahasiswa atau $70 \%$ mahasiswa berkemampuan dibawah kategori baik

Meskipun demikian perolehan hasil mahasiswa padan tindakan siklus I belum 
memuaskan tetapi sudah mulai memahami langkah-langkah pendekatan kontekstual. Terlihat melalui perolehan mahasiswa yang sudah mengalalmi kemajuan bila dibanding sebelum penerapan pendekatan contekstual. Hal ini dilihat dari nilai rata-rata kelas 48,15\% menjadi $61,75 \%$. Melihat hasil yang dicapai mahasiswa masih rendah maka, pembelajaran pada siklus II masih perlu dilanjutkan

\section{Siklus II}

Pada siklus II dosen telah melakukan penyempurnaan pada setiap kegiatan perkuliahan melalui pendekatan CTL sehingga perkulihan berjalan dengan lancar tanpa hambatan sehingga hasil yang diperoleh menunjukkan kemajuan yang pesat. Pada perkuliahan tersebut dosen memperhatikan kelemahan pada siklus I sehingga semua Fase dalam perkuliahan telah tercapai.

Untuk mengetahui pemahaman mahasiswa terhadap materi pelajaran diadakan tes evaluasi secara individu pada pertemuan berikutnya. Prestasi mahasiswa berdasarkan tes tertulis skor rata-rata kelas 83,78. Prestasi tersebut berada pada kualifikasi amat baik (A). setelah hasil tes dianalisis data menunjukkan bahwa ada 12 siswa yang mendapat nilai amat baik, 7 mahasiswa mendapat nilai baik, 1 mahasiswa mendapat nilai cukup, dan tidak ada lagi mahasiswa mendapat nilai kurang dan kurang sekali. Dengan demikian hanya 1 mahasiswa atau 5 persen mahaiswa berkemampuan di bawah kategori baik

Berdasarkan observasi dan refleksi yang dilakukan, hasil yang diperoleh dari pelaksanaan pratindakan, pelaksanaan siklus I, pelaksanaan siklus II, menunjukkan bahwa target keberhasilan yang telah ditetapkan telah tercapai. Untuk melihat perbandingan perolehan ketuntasan hasil belajar mahasiswa dari setiap siklus dapat dilihat pada grafik berikut:

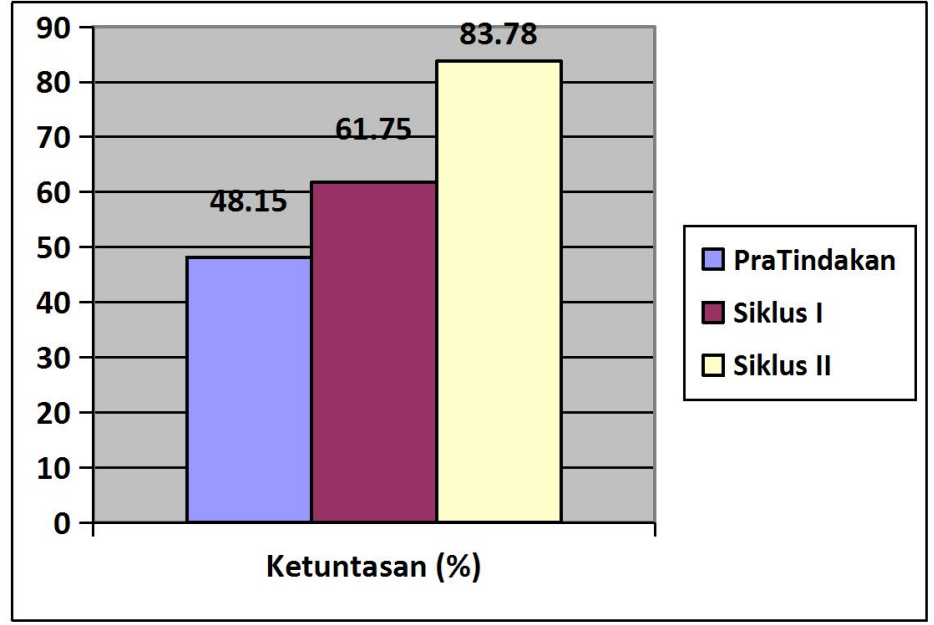

Grafik1. Ketuntasan Belajar Mahasiswa

Bila dibandingkan pertemuan pertama sampai terakhir pencapaian skor hasil belajar mahasiswa sangat meningkat. Sehingga dapat disimpulkan bahwa secara umum peningkatan hasil belajar PKn1 mahasiswa melalui penerapan pendekatan contekstual teaching and learning (CTL) sudah memuaskan. Dan kepada semua pihak yang akan melanjutkan penelitian ini terkait dengan penerapan pendekatan contekstual (CTL) diharapkan dapat menyempurnakan masalah-masalah yang belum terselesaikan oleh peneliti.

\section{KESIMPULAN \& SARAN}

\section{Kesimpulan}

Secara umum dapat disimpulkan bahwa upaya peneliti menerapkan pendekatan CTL dalam meningkatkan hasil belajar PKn1 mahasiswa adalah sebagai berikut :Penerapan pendekatan contekstual teaching and learning (CTL) dalam proses perkuliahan di Prodi PGSD UNM Kampus Parepare pada mata kuliah PKn1 dapat meningkatkan hasil belajar mahasiswa. Di mana peneliti telah memaksimalkan perkuliahan dengan mengikuti tahapan perkuliahan sesuai dengan pendekatan yang digunakan. Sehingga nampak adanya perubahan-perubahan yang terjadi dalam setiap 
siklus. Di mana tidak ada lagi mahasiswa yang pasif dalam pembelajaran. Dan secara keseluruhan semua mahasiswa telah mampu mengerjakan tugas yang telah diberikan. Hal tersebut nampak ketika proses belajar mengajar berlangsung.

\section{Saran}

1. Bagi para pendidik hendaknya menerapan pendekatan contekstual teaching and learning (CTL) karena sangat baik diterapkan untuk meningkatkan hasil belajar mahasiswa dan kerja sama mengerjakan soal sesuai dengan konteksnya.

2. Kepada semua pihak yang akan menerapkan suatu pendekatan tertentu dalam pembelajaran, terlebih dahulu dilakukan sosialisasi sebelum pendekatan itu diterapkan.

3. Bagi Program Studi PGSD UNM Kampus Parepare, bahwa pendekatan contekstual teaching and learning (CTL), dapat dijadikan sebagai salah satu alternatif dalam meningkatkan hasil belajar mahasiswa khususnya dalam mata kuliah PKn1

\section{DAFTAR PUSTAKA}

Azaria, 2005. Model Pembelajaran di Sekolah Dasar. Universitas Negeri Makassar.

Azis Wahab, 1996. Pendidikan Pancasila dan Kewarganegaraan Direktorat Jenderal Pendidikan Tinggi. DEPDIKBUD. Jakarta

Bobbi Deporter 1992. Strategi Pembelajaran. Jakarta : Kencana

Budiana 1996. Pendidikan Pancasila dan Kewarganegaraan. Jakarta : Balai Pustaka

Depdiknas 2006. Pembelajaran Berbasis Kontekstual.

Elliot, John. 1993. Action Research For Education Change. Philadelphia: Open University Press.

Etin Solihatin 2007. Cooperative Learning. Jakarta : Bumi Aksara

Endang 1989. Dalam KTI Agustbain Efektifitas Pembelajaran PPKn Terhadap Peningkatan Moralitas Murid SD. Universitas Negeri Makassar

Hasan, Fuad 1993. Dalam KTI Agustubain Efektifitas Pembelajaran PPKn
Terhadap Peningkatan Moralitas Murid $S D$. Universitas Negeri Makassar.

Nurhadi, 2004. Pembelajaran Kontekstual dan Penerapannya Dalam KBK. Malang Universitas Negeri Malang

Rusyan, 1990. Psikologi Pendidikan. Jakarta : Bina Aksara

Sujana, Nana 2002. Dasar-dasar Proses Belajar Mengajar. Bandung : Sinar Baru Algesindo

Suryosubroto, 1990. Tata Laksana Kurikulum. Jakarta : Rineke Cipta

Tiro, M. A. 2005. Menulis Karya Ilmiah untuk Pengembangan Profesi Guru. Makassar : Andira Publisher

Undang-undang Republik Indonesia No 20 Tahun 2003 Tentang Sistem Pendidikan Nasional. Depdikbud Jakarta 